\title{
Vena Cava Endothelium
}

National Cancer Institute

\section{Source}

National Cancer Institute. Vena Cava Endothelium. NCI Thesaurus. Code C49318.

The layer of cells that line the lumen of the vena cava. 